
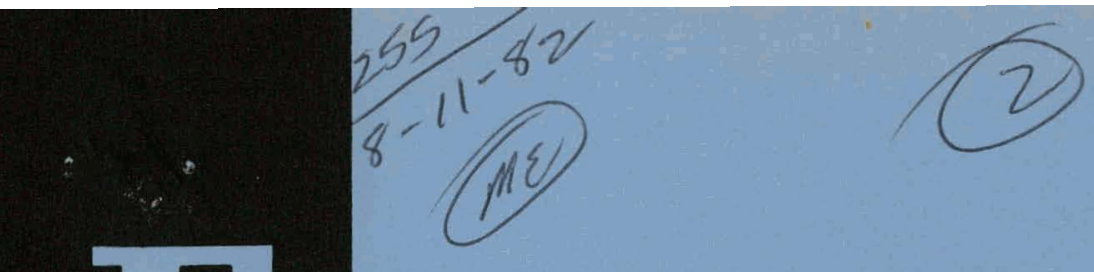

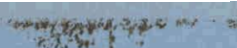

DOE/RA/20225-T1

(DE82007223)
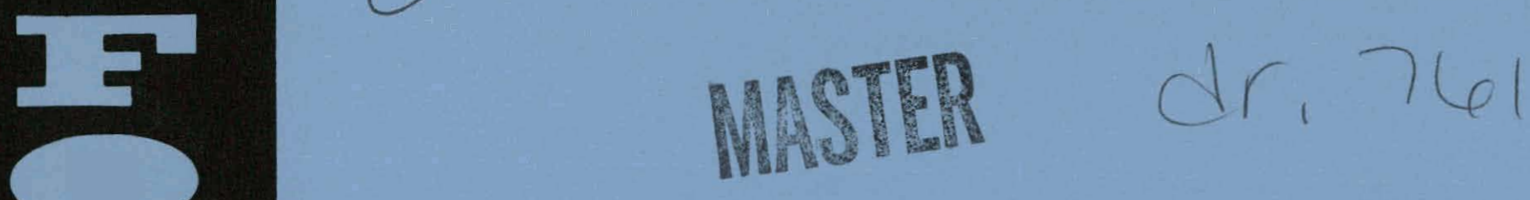

\title{
PLANNING AND INITIATION OF DETAILED ENGINEERING DESIGN FOR THE GREAT PLAINS COAL GASIFICATION PROJECT
}

Final Report

January 1981

Work Performed Under Contract No. FC03-79RA20225

ANG Coal Gasification Company

Detroit, Michigan

\section{U. S. DEPARTMENT OF ENERGY}




\section{DISCLAIMER}

This report was prepared as an account of work sponsored by an agency of the United States Government. Neither the United States Government nor any agency Thereof, nor any of their employees, makes any warranty, express or implied, or assumes any legal liability or responsibility for the accuracy, completeness, or usefulness of any information, apparatus, product, or process disclosed, or represents that its use would not infringe privately owned rights. Reference herein to any specific commercial product, process, or service by trade name, trademark, manufacturer, or otherwise does not necessarily constitute or imply its endorsement, recommendation, or favoring by the United States Government or any agency thereof. The views and opinions of authors expressed herein do not necessarily state or reflect those of the United States Government or any agency thereof. 


\section{DISCLAIMER}

Portions of this document may be illegible in electronic image products. Images are produced from the best available original document. 


\title{
DISCLAIMER
}

\begin{abstract}
"This report was prepared as an account of work sponsored by an agency of the United States Government. Neither the United States Government nor any agency thereof, nor any of their employees, makes any warranty, express or implied, or assumes any legal liability or responsibility for the accuracy, completeness, or usefulness of any information, apparatus, product, or process disclosed, or represents that its use would nul infrings privately owned rights. Reference herein to any specific commercial product, process, or service by trade name, trademark, manufacturer, or otherwise, does not necessarily constitute or imply its endorsement, recommendation, or favoring by the United States Government or any agency thereof. The views and opinions of authors expressed herein do not necessarily state or reflect those of the United States Government or any agency thereof."
\end{abstract}

This report has been reproduced directly from the best available copy.

Available from the National Technical Information Service, U. S. Department of Commerce, Springfield, Virginia 22161.

Price: Printed Copy A03

Microfiche A01

Codes are used for pricing all publications. The code is determined by the number of pages in the publication. Information pertaining to the pricing codes can be found in the current issues of the following publications, which are generally available in most libraries: Energy Research Abstracts, (ERA); Government Reports Announcements and Index (GRA and I); Scientific and Technical Abstract Reports (STAR); and publication, NTIS-PR-360 available from (NTIS) at the above address. 
DOE/RA/20225-T1

(DE82007223)

Distribution Categories UC-89 and UC-90c

PLANNING AND INITIATION OF DETAILED ENGINEERING DESIGN

FOR THE GREAT PLAINS COAL GASIFICATION PROJECT

Final Report

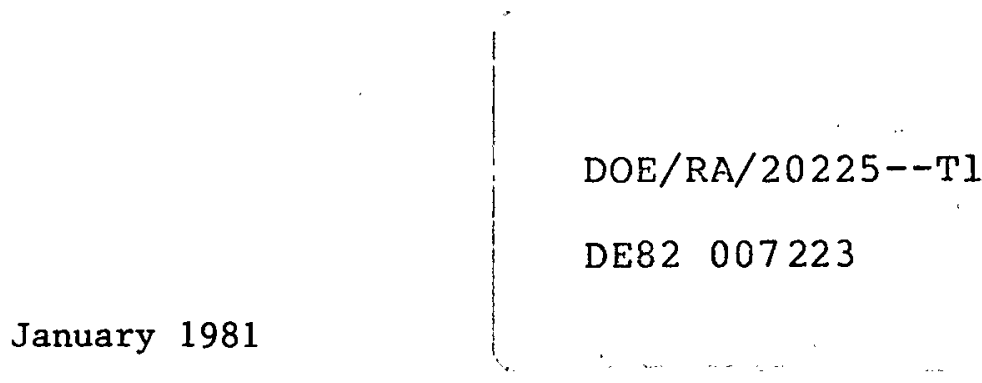

$f$

Cooperative Agreement Contract No. DE-FC03-79RA20225

ANG Coal Gasification Company

Detroit, Michigan 
THIS PAGE

\section{WAS INTENTIONALLY LEFT BLANK}




\section{Pages}

I. Introduction

II.

Engineering

A. Preliminary Engineering 5

B. Technical Procurement Support 6

C. Detailed Design 9

1. Plant Layout 12

2. Piping 12

3. Civil/structural 13

4. Instrumentation 15

5. Electrical 15

6. Building Design 16

III.

Procurement

A. Procurement Activity Chronological

B. Procurement Progress and Manpower

IV.

Project Controls

23 
Introduction

In December of 1979 the Department of Energy entered into a Cooperative Agreement with ANG Coal Gasification Company for $\$ 25$ million for the purpose of initiating detailed engineering for the Mercer County, Great Plains Coal Gasification Project. This report is the "final report" Deliverable under the Cooperative Agreerient as indicated on page 2, item (b) of Attachment $B$ of the Cooperative Agreement.

The work activities outlined in this report were for the purpose of organizing, planning and initiating the detailed engineering design for the Mercer County, Great Plains Coal Gasification Project to allow for the earliest possible start of full field construction after completion of project financing arrangements.

ANG retained two well-known engineering/construction firms, C. E. Lummus of Bloomfield, NJ and Kaiser Engineers of Oakland, CA (hereafter referred to as CELKE) and the activities described in this report were, for the most part, performed by CELKE at ANG's direction. Some design review and equipment procurement activities were carried out by the Lurgi Corporation in River Edge, NJ and Frankfurt, Germany (hereafter referred to as LURGI). A minor amount of work was also carried out by outside consultants, vendors and testing agencies. All work performed under this Cooperative Agreement was accomplished between September, 1979 through November, 1980 and all statements regarding current project status are as of the end of November, 1980 .

A major portion of the preliminary engineering and the detailed cost estimate for the Project had been completed by June, 1978. From then until September, 1979 the Project had been on "hold" awaiting permanent financing. A small group of key personnel were maintained at CELKE to finalize preliminary design and project controls procedures and to update costs and cchedules. 
In order to provide sufficient design information and construction materials for a hoped-for full field construction start in the spring of 1980 it was necessary to begin remobilizing project manpower at CELKE by September, 1979 and initiate detailed design shortly thereafter. However, by mid-summer of 1979 it became obvious that permanent financing would not be in place prior to September, 1979. This Cooperative Agreement was therefore intended to provide funding for a portion of the activities necessary to support the 1980 construction program.

Although delays in securing permanent financing (primarily due to court appeals of the FERC certificate granted to the gasification Project in October, 1979) further delayed the full construction start until 1981, the Cooperative Agreement assisted us in projert remobilization and significant progress in the detailed design, project controls and procurement areas have been accomplished.

While it is outside the scope of the Cooperative Agreement, ANG initiated a limited field construction program in August, 1980. The purpose of this $\$ 8.8 \mathrm{MM}$ dollar program was to prepare the plant site such that construction activities could be accelerated as soon as full ronstruction funde were released. In brief, this consisted of rough grading for about half the plant site; piling for the gasification, shift conversion; gas cooling and Rectisol areas; and erection of a warehouse, maintenance building and gatehouse/medical building. All of this work was performed on a subcontract basis. As of the end of November, 1980 this program was about 408 complete. 
Detailed engineering for the project was 10.48 complete by the end of November, 1980. Most of this progress, measured in terms of completed documents (drawings, models, specifications, data sheets, requisitions, bid analyses, etc.), had been accomplished over the previous seven months. Engineering personnel was maintained at a fairly constant level (180-220 people) over that period.

During the latter part of 1979 and the first quarter of 1980, engineering activity was concentrated on the mobilization and orientation of personnel, completion of preliminary engineering and resolution of items open at the time of the 1978 project shutdown.

Detailed engineering progress from May, 1980 through November, 1980 is tabulated below:

\begin{tabular}{|c|c|c|c|c|c|c|}
\hline May & June & July & Aug. & Sept. & Oct. & Nov. \\
\hline 3 & 4.1 & 5.3 & 5.5 & 6.8 & 8.5 & 10.4 \\
\hline
\end{tabular}

Engineering*

Progress

(1980)

Detailed engineering proceeded in accordance with the construction sequence requirements. Concentration was on plant site grading, underground piping and electrical work, piling/foundations and construction facilities including permanent buildings to be used during construction. significant progress was made in structural steel and piping design for areas which have long construction durations and in areas requiring little, if any, vendor engineering to finalize detailed engineering. We proceeded with the requisitioning, proposal evaluation and bid analyses steps for major equipment and systems.

Monthly reports prepared and submitted to DOE during the period covered by the Cooperative Agreement provide a brief outline of engineering activities and accomplishments. Th1s section of the report summarizes and supplements the monthly reports. To properly identify project areas while summarizing engineering activities, a simplified listing is shown on the next page.

*Excludes process and preliminary engineering. 
Area No.

0200

0300

0400

1100

1200

1300

1400

1600

1700

1800

1900

2.000

3000

4000

4600

4900

5100

5300

5400

5500

6000

7100

8100

8200

8300

8600

9100

Area Name

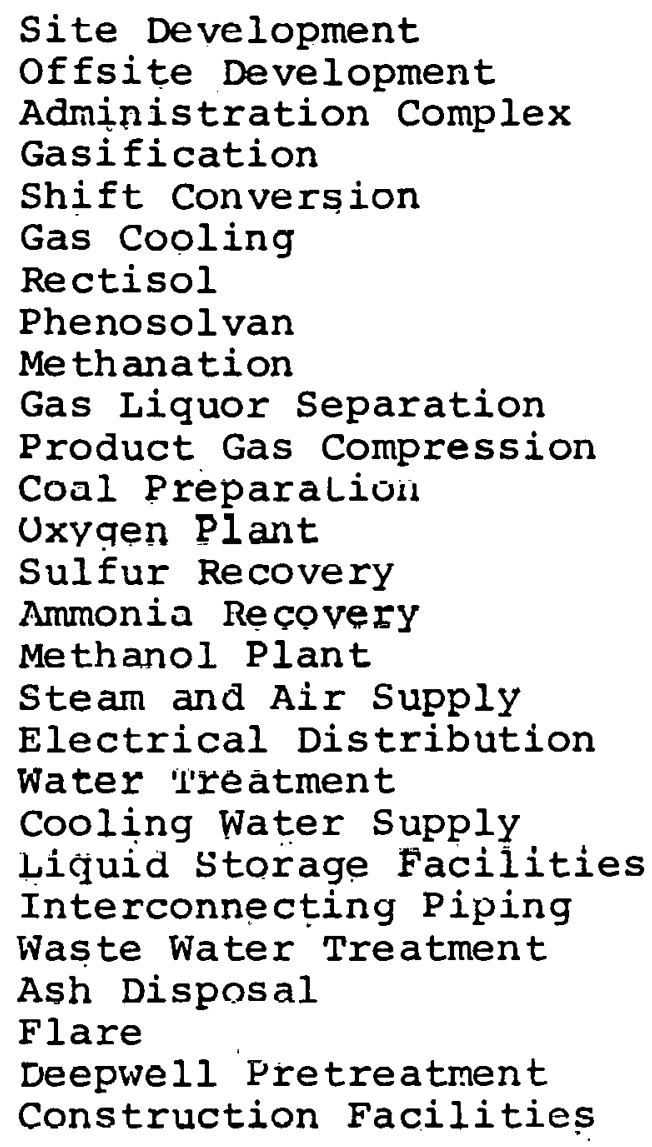

* Condensed from complete project listing of area numbers. 
For this project, preliminary engineering is generally defined as a consistent set of process and utility flow diagrams, piping and instrument diagrams (P\&ID's), plot plans, equipment data sheets, equipment specifications, project engineering specifications, layout drawings, mechanical arrangement drawings and electrical schematics.

When the project was restarted in the fall of 1979 some preliminary engineering work was necessary for most project areas. Due to previous funding limitations, changes had been made to one process unit without reflecting these changes in the preliminary engineering documents for other units. Therefore, it was necessary to make an overall review of the preliminary engineering performed to date in order to assure consistency. Other reasons for the modification of preliminary engineering were design improvements based on operational information from sasol (our consultants in South Africa), engineering studies, discussions with vendors and consultants, changes which resulted from earlier cost reduction programs and the issuance of upaated industrial codes, standards and environmental regulations.

The updating of basic design documents was essentially completed during March, 1980. For areas where the vendors have a significant design responsibility (Oxygen Plant Area 3000; Methanol Recovery - Area 4900; Water Treatment Area 5400; Wastewater Treatment - Area 8100; Ash Handling Area 8200), the basic design documents remain at a lower level of completeness until vendor technical documentation is available.

During the course of detailed engineering it was expected that preliminary engineering documents would need to be modified. In a number of instances, especially for flow diagrams and specifications, the revised preliminary engineering documents become the final approved for construction (AFC) documents. P\&ID's and plot plans were updated as a result of the detailed piping design. Equipment data sheets which initially contained basic process data were made mechanically complete and then further updated to reflect the equipment actually purchased. The initial issue of the preliminary engineering documents represent a necessary baseline for monitoring project design changes. 
Technical procurement support was a major engineering activity in 1980. For the total project, 2574 requisitions for 2574 major equipment items and systems are to be issued and purchase orders placed. As of the end of November, 1980 requisitions to vendors for 1301 items or $50.5 \%$ of the total has been issued.

For the main process areas ( 1100 thru 1900) the technical data associated with requisitions for over $78 \%$ of the major equipment and systems was issued. For the other project units, technical data for requisitions were issued for many significant equipment items and systems such as deaerator, feedwater pumps, superheaters (Area 5100); transformers, switchgear (Area 5300); cooling water pumps (Area 5500); water treatment packages (Area 5400); API separator, multieffect evaporator, waste incinerator, vacuum drum filter (Area 8100). Bid tabulations have been issued for 634 equipment items and systems.

For the project, a total of 47 subcontract requisitions are to be issued and purchase orders placed. As of the end of November, 198016 requisitions, or 348 of the total, have been issued. Among these are the large design/fabricate/ erect subcontracts for the utility steam generators, oxygen plant and cooling tower for which items bid tabulations have been issued. The remaining subcontract requisitions issued were associated with the Iimited 1980 construction program and the construction housing facilities.

For the project, a total of 520 commodity requisitions will eventually be issued and purchase orders placed. As of the end of November, 1980, however, we have issued 9 requisitions or $1.7 \%$ of the total and these requisitions are very significant since they cover the plantwide supply of instrumentation hardware, control/relief valves, above and below ground plping and electric conduit and wire.

The engineering activity associated with major equipment and subcontract procurement is similar. The first step is to complete from a process, mechanical and electrical standpoint all data sheets. For most pressures, vessels, columns and reactors and some heat exchangers, drawings completely describing the equipment are also prepared. The standard project equipment sperifications are usod for many oomponente 
(vessels, steam turbines, pumps, compressors, tanks, etc.); however, individual specifications are prepared for more complex and unusual equipment items and for equipment packages such as the gasifier grates, steam generators, superheaters, water and wastewater treatment systems, refrigeration systems, cooling tower, evaporators, dust collectors, oxygen plant, etc. For subcontracts, individual specifications are always prepared to clarify the work scope and applicable field conditions. Equipment guarantees and performance test requirements are jointly established between the engineering and procurement groups. In some cases field trips are necessary to verify that vendors have the technical expertise and experience necessary to design and manufacture specialized equipment and systems. After all technical documentation is prepared by engineering, it is issued to procurement.

Much engineering time was spent reviewing the proposals submitted to vendors and writing technical summaries. In some cases technical clarification meetings with vendors were necessary prior to completing the technical evaluation.

The activities to support commodity procurement are somewhat different. Once specifications are complete, only the quantities and sizes or other distinguishing characteristics for the commodity items need to be identified before the technical information is forwarded to procurement. When received, vendor proposals will require the same thorough review as the equipment proposals.

Specifications and data sheets have been prepared by engineering but requisitions have not yet been issued to vendors for many items not mentioned above. These include much of the material handing equipment in coal preparation (2000) and Ash Handling (8200) such as conveyors, trippers, feeders, dust collectors, and ash dewatering systems; motors and transformers (5300) structural steel; and constructionrelated items such as a concrete batch plant, vehicles, trailors and construction equipment. Other procurement activities assoclated with engineering were also performed. 
From a design, spare parts, vendor service or maintenance viewpoint, it is desiralle to standardize many components for equipment and commodities. These included small pumps, rotating machinery accessories (bearings, mechanical seals, shaft sleeves, etc.), conveyor idlers, motors, circuit breakers, instrumentation (transmitters, level and pressure measuring elements, control valve activators, vibration detectors, etc.). Implementation plans included placing together common items in a single requisition and the independent evaluation and selection of components prior to requisitioning equipment containing these components, this program being carried forward in cooperation with the procurement group.

During the first quarter of 1.980, engineering personnel made a final review of the Approved Vendors Iist for equipnint and commodities. Engineering provided input regarding vendore' experience, manufacturing quality control, past performance and engineering capabilities, esper:i illy for tochnioally-oophisticated eyuipllent. 
A summary of detailed engineering progress for Project Areas greater than $10 \%$ complete as of the end of November, 1980 is shown below.

Greater than $40 \%$ complete

0300 - Offsite Development

$25-40 \%$ Complete

0400 - Administration Complex
1200 - Shift Conversion
9100 - Construction Facilities

$10-25 \%$ Complete

0200 - Site Development
1100 - Gasification
1300 - Gas Cooling
1400 - Rectisol
1700 - Methanation
3000 - Oxygen Plant
5100 - Steam and Air Supply
5300 - Electrical Distribution
5500 - Cooling Water Supply
7100 - Interconnecting Piping
8100 - Waste Water Treatment

Although some detailed engineering was performed for almost every unit, it is necessary to examine the progress measurement method before briefly describing these accomplishments. The Engineering Progress Summary Sheet is shown on the next page. It can be seen that activities associated with the issuance of Approved for construction (AFC) drawings and the completion of piping model tables account for over $80 \%$ of the measured progress. At this stage of detailed engineering, many of the hours spent preparing as yet uncompleted drawings and models are not included in progress measurement. The progress monitoring system used by the project controls group is, however, constructed to accommodate this.

Many of the detailed engineering activities in 1980 were devoted to providing the design drawings for facilities which will be needed prior to the build-up of site construction labor and the delivery of equipment and materials. The highest completion level listed above, the Offsite Development (0300), is due primarily to the development and issuance of drawings for site access roads and railroad spurs. Significant progress for the Administration Complex (0400) and the construction Facilities (9100) is attributable to completing design work for permanent building which will be used during onstruction, construction utility systems (water, electric power, drainage, commmication) and construction housing facilities, as well as completing the 
EMOMNEERINB FAOCAESS SUMAARY ON ACTUNT

TOTAL PROJECT

cos ro. stererses

rencoo enome: 11/30/80

\begin{tabular}{|c|c|c|c|c|c|c|c|c|}
\hline \multirow{2}{*}{\multicolumn{2}{|c|}{ Activitr }} & \multirow{2}{*}{$\begin{array}{c}\text { rotal } \\
\text { mo. } \\
\text { orighintering } \\
\end{array}$} & \multicolumn{2}{|c|}{ COMmETEo } & \multirow{2}{*}{$\begin{array}{l}\text { SCHEOULED } \\
\times \\
\text { COMPLETE } \\
\text { TO OATE }\end{array}$} & \multirow{2}{*}{$\begin{array}{c}\text { ACTUAL } \\
\% \\
\text { Complete } \\
\text { TO DATE }\end{array}$} & \multirow{2}{*}{ wro } & \multirow{2}{*}{$\min _{n=0}^{\infty}$} \\
\hline & & & $\begin{array}{c}\text { THIs } \\
\text { MONTH }\end{array}$ & TO & & & & \\
\hline \multirow{2}{*}{ 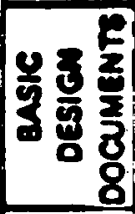 } & $\begin{array}{l}\text { POI OS A UF OS } \\
\text { DSUED AFD }\end{array}$ & $339 / 242$ & B & 236 & 71.4 & 69.6 & 1.9 & 1.3 \\
\hline & $\begin{array}{l}\text { ENBINEERING STECS } \\
\text { DSUED AFC }\end{array}$ & $56 / 56$ & D & 55 & 100 & 98.2 & .1 & .1 \\
\hline \multirow{3}{*}{$\frac{3}{3}$} & $\begin{array}{l}\text { DATA SHEETS OA SPEES } \\
\text { DNUED FOA OUOTATION }\end{array}$ & $2,574 / 2,202$ & 2 & 1,199 & 69.0 & 46.6 & 5.2 & 2.4 \\
\hline & $\begin{array}{l}\text { notass } \\
\text { Dised }\end{array}$ & $2,514 / 2,142$ & 91 & 437 & 49.8 & 17.4 & 3.8 & .66 \\
\hline & $\begin{array}{l}\text { OUTIME VENDON } \\
\text { DRAMING APPAOVEO }\end{array}$ & $2,574 / 2,199$ & 0 & 0 & $\mathbf{0}$ & 0 & 3.6 & - \\
\hline \multirow{8}{*}{ 哥 } & $\begin{array}{l}\text { MSTMUMENT OATA SHEETS } \\
\text { DSSUED FOR OUOTATION }\end{array}$ & $1,014 / 2,355$ & 90 & 2,445 & 21.0 & 22.2 & 1.9 & .42 \\
\hline & $\begin{array}{l}\text { mooel TAOLES RELEASED } \\
\text { FOA isometaics }\end{array}$ & $130 / 23$ & 11 & 11 & 0 & 8.5 & 7.5 & .64 \\
\hline & $\begin{array}{l}\text { DSOMETAICS ISSUED } \\
\text { AFC }\end{array}$ & $10,845 / 200$ & D & 0 & 0 & 0 & 7.9 & - \\
\hline & $\begin{array}{l}\text { AEVISHONS TO AFC } \\
\text { ISOMETAICS }\end{array}$ & $6,598 / 0$ & D & 0 & 0 & 0 & 1.0 & - \\
\hline & $\begin{array}{l}\text { DRAmmes ISSUEO } \\
\text { AFC }\end{array}$ & $4,788 / 1,306$ & 45 & 351 & 9.1 & 7.3 & 54.8 & 4.0 \\
\hline & $\begin{array}{l}\text { AEVISIONS TO AFC } \\
\text { DAAMINGS }\end{array}$ & $4,364 / 2,301$ & 27 & 57 & 1.7 & .4 & 9.0 & .04 \\
\hline & $\begin{array}{l}\text { COMMODITY AEQUISITIONS } \\
\text { SSSUED FOR OUOTATION }\end{array}$ & $520 / 125$ & 1 & 9 & .8 & 1.7 & 1.0 & .02 \\
\hline & $\begin{array}{l}\text { SUBCONTAACT PACKAGES } \\
\text { ISSUEO FOR OUOTATION }\end{array}$ & $47 / 19$ & $\mathbf{0}$ & 16 . & 25.5 & 34.0 & 2.3 & .78 \\
\hline & & & & & & TOTAL & 100.0 & 10.4 \\
\hline
\end{tabular}


specifications for construction equipment. Much of the progress for Site Development (0200) is associated with this issuance of drawings for site rough grading and an-site roads and drainage structure.

For Gasification (1100), Gas Cooling (1300), Rectisol (1400), Methanation (1700) and Wastewater Treatment (8100), measured progress is primarily due to technical activities associated with the procurement of major equipment. The higher completion level for Shift conversion (1200) is due to piping model progress plus technical procurement activity. Electrical Distribution (5300) progress is attributable to the issuance of underground electrical conduit drawings, plus technical procurement activity. Interconnecting Piping (7100) progress is a result of the completion of a portion of the piping model and the issuance of underground piping drawings. The Oxygen Plant (3000), Steam and Air Supply (5100) and Cooling Water Supply (5500) show significant progress because specifications have been prepared, vendor proposals reviewed and bid evaluations completed for three large subcontracts; the $3100 \mathrm{~T} / \mathrm{D}$ oxygen plant, the utility steam generators and the coling tower. It is noted that piping model progress has also been substantial for Gasification (1100), Gas Cooling (1300), Rectisol (1400), Phenosolvan (1600) and Ammonia Pécovery (4600).

Prior to beginning detailed engineering for the units for which the process design was done by Lurgi, kickoff meetings were held with Lurgi and, where applicable, SASOL representatives. These meetings were held during the first half of 1980 for Gasification (1100), Shift Conversion (1200), Gas Cooling (1300), Rectisol (1400), Phenosolvan (1600) and Gas Liquor Separation (1800), and their purpose was to assure that all technical data from Lurgi had been properly incorporated into flow diagrams, P\&ID's and data sheets and that the latest operating data from SASOL was available prior to the commencement of detailed design. 
A brief description of engineering activities and accomplishments by discipline follows:

IIC.1. Plant Layout

About one quarter of the 351 drawings issued Approved-Forconstruction (AFC) to date are considered to be plant layout drawings. These include detailed plot plans and equipment arrangement drawings for the process and utility areas as well as layouts for most of the process buildings, coal conveyors, control buildings, roads and administration facilities.

The overall plant plot plan which is based on the individual area layouts has also been completed. This was coordinated with Coteau and Basin, who own the adjacent facilities, in order to make final decisions on the location for all wastewater and storm drainage ponds and the interconnection of the offsite and on-site road network. Plant layouts were issued for construction facilities, including the location for topsoil which is to be stored after removal from the main construction areas.

On an overall basis, the plant layout activity is considered to be about $90 \%$ complete. In most cases the issuance of these plant layout drawings are, from a physical viewpoint, the basis for much of the design work carried out during the later stages of detailed engineering.

IIC. 2 . Piping Piping dcsign conoentrated on two arcas:

1) underground systems which will be installed during the early stages of construction.

2) above ground piping for units which have high density piping with cormesmondingly long installation durations (Gasification Pactisol, Interconnecting Piping) and/or units where reasonable design progress could be made without vendor drawings (Shift Conversion, Gas cooling, Phenosolvan, Methanation, Ammonia Recovery).

Above fround piping for most process units is being dane by use of the design model (piping isometric drawings are made directly from the scaled plastic model rather than from orthographic drawings). As of the end of November, 1980 model progress for the various process areas is shown below. 


\section{\& Complete}

Gasification
Shift Conversion
Gas Cooling
Rectisol
Phenosolvan
Methanation
Ammonia Recovery
Interconnecting
Piping

$(4600)$

(7100)
50

90

10

10

30

10

Although the percentage of piping placed on the models for each area varies greatly, all areas have been through at least the initial stages of model preparation. These preparations include making the plastic models for individual equipment items and major structural steel, placing the steel and equipment on the precut model boards in accordance with the plot plan, making piping layout drawings for major lines in accordance with the P\&ID's and performing a preliminary thermal stress analysis where necessary for these major lines to justify the routing.

As of the end of November, 1980, underground piping dravings (including firewater, utility water and drainage piping) were about $50 \%$ complete on a plantwide basis.

IIC. 3.

\section{Civil/Structural}

As expected, detailed engineering work in 1980 concentrated on the civil/structural areas where a major effort is required during the early field construction period. About $25 \%$ of the engineering personnel assigned to the project task force were dedicated to this discipline during 1980. As a result the majority of the drawings issued AFC thus far fall into this category.

Civil work is essentially complete for site grading, on the offsite roads, railroad spurs and the construction housing facilities. Design drawings for open channel drainage and the earthen storage ponds for stormwater, coling water and wastewater are about $50 \%$ complete. To provide additional information for foundation design, soil borings were obtained and analyzed for the gasification building and cooling tower areas. 
Structural engineering has progressed in a number of areas. Piling design was completed for the Gasification (1100), Shift Conversion (1200), Gas Cooling (1300) and Rectisol (1400) areas and is 25 to 508 complete for Methanation (1700), Coal Handling (2000) and Ash Handling (8200). Piling design drawings for the Oxygen Plant (3000), Steam and Air Supply (5100) and Cooling Water Supply (5500) must await vendor information; however, pile types and spacing have been tentatively chosen.

Foundation drawings have been completed for the Administration Complex (0400) and are $90 \%$ complete for the gasifier building. Foundation design has been started for the major electrical substations and control buildings. Foundation and structural steel drawings are about $50 \%$ complete for the main pipeways, both within process units and between them. Foundation and structural steel design for equipment support is underway for most main process units (1100 thru 1900) as well as for uoal Handling Ammoia Recovery (4600) and Liquid Storage Facilities (6000).

Anuther activity which was amss-discipline in nature but handled primarily by civil personnel was the ANG/Basin/Coteau (ABC) Interface Document. This document was 95\% complete by Novenber, 1980.

This document was necssary for two reasons:

1) The Basin Electric Antelope Valley power plant and the Coteau lignite mine are adjacent to the ANG property, requiring the coordination of elevations and drainage patterns.

2) The several agreements between ANG, Basin and coteau require physical interfaces for piping coll conveyors and electrical cables.

The ANG/Basin/Cotcau(ABC) Interface Documentation was prepared by $A N G$ and CELKE engineering personnel so that these physical interlaces were defined in writing and with applicable drawings. It was necessary to investigate several of these interfaces to assure that the coal gasification plant design was not compromised by the contents of the $A B C$ Interface Document. 
Detailed engineering for instrumentation and control systems made steady progress since the second quarter of 1980. By early June the control philosophy and instrument nomenclature had been reviewed and updated for over 808 of P\&ID's. Instrument lists have been compiled for all main process units (1100 through 1900), Ammonia Pecovery (4600), Steam and Air Supply (5100), Water Treatment (5400), Cooling Water Supply (5500), Liquid Storage Facilities (6000), Wastewater Treatment (8100) and Deepwell Pretreatment (8600). Instrument data sheets which completely describe the design parameters for control valves, relief valves, primary measurement elements (pressure, temperature, level), analyzers, transmitters and other instrumentation hardware have been issued for 2445 items or 22.28 of the 11,014 items required for the project.

Specifications to be used for procurement were prepared and issued for all hardware items mentioned above plus control panels and annunciators. Technical packages have been prepared and requisitions issued for control valves, safety valves and electronic transmitters. The vendor proposals for these items are currently under review.

Instrumentation personnel also prepared the instrumentation portions of vendor engineered equipment packages and later analyzed the vendor proposals for conformance.

After numerous studies carried out by instrumentation personnel, it was determined that a CRT-based, digital instrumentation system should be used for a majority of the plant areas. Subsequent to the selection of a digital system supplier, early in 1980 a new design basis document was prepared and issued which completely described the hardware and software to be used for the digital portions of the instrumentation and control systems.

\section{IIC.5. Electrical}

Electrical engineering design has concentrated on the preparation and issuance of one-line electrical schematics, the analysis of the plantwide electrical distribution systems, the preparation of underground electrical distribution drawings and the design of electrical systems and hardware to be used during the construction period.

One-line diagrams were issued for the main electrical substation and for $90 \%$ of the process and utility units. Plantwide short circuit and power factor studies were completed. Area electrical classification diagrams were issued for all portions of the plant. 
The main underground electrical conduit routing studies are $90 \%$ complete. Underground electrical distribution drawings and grounding system drawings are about 50\% complete. Drawings for the installation of area lighting (generally located at the perimeter of the process and utility units) are about 908 complete.

Substation layouts are $75 \%$ complete for the main process units (1100 through 1900) and 25 - 50\% complete for the remaining units.

Specifications were prepared and issued for all major transformers, switchgear and motor control centers as well as for lighting fixtures. Technical packages were prepared and requisitions issued for these iterns and vendor proposals evaluated.

Motor specifications were prepared and issued and vendor equipment package proposals containing electrical equipment were reviewed.

The design of electrical power systems to support construction is essentially complete. Ioads were estimated, one-line schematics and cable distribution drawings issued and transformers/switchgear were specified.

IIC. 6 .

Building Design

The initial engineering effort was to review the design requirements for the seventy-plus buildings included on the plant site. The buildings were categorized in accordance with the following characteristics: type of equipment contained, fire/explosion hazards, floor loadings, crane capacity, intemal environmental needs, etc. The desire to combine a pleasing appearance with function and cost effectiveness was also evaluated. The pre-engineered building was chosen in most instances where safety requirements, crane capacity and size or height are not technological barriers. Specifications were prepared and issued describing the general requirements for architectural, structural, mechanical and electrical design for the building.

Building design for the Administration Complex is about 908 com plete. A centralized mechanical complex (heating, ventilation, air conditioning and water supply) was designed for the seven large buildings in this area which are all of the pre-engineered type. More than half of the required drawings were issued AFC. 
Significant progress was made in four other areas: coal preparation (2000) buildings for coal grinding, screening, storage and the conveyor transfer towers; gasification (1100) building, which houses all the primary gasification equipment and coal distribution conveyors; control rooms and major electrical substations; construction camp housing.

Equipment layouts and concrete/structural steel design for the coll preparation (2000) buildings are $50 \%$ complete. In the gasification building, where the equipment support steel is also used as building steel, the major emphasis has been on the design of mechanical systems which is now about 508 complete. With equipment requirement established, architectural, mechanical and electrical work has proceeded for the control rooms and substations and is about 25\% complete.

Layouts and specifications for the prefabricated offsite construction housing modules have been completed and issued.

Detailed design work has been initiated for the cooling water pump and fire water pump buildings.

Detailed design for other buildings which house parts of, or all of, process and utility units (oompressor buildings, boiler house, water treatment buildings, etc.) will begin after vendor drawings are available. 
Procurement activity began in the last quarter of 1979 with the release of Lurgi to begin procurement of their longdelivery, proprietary equipment. As CETKE's engineering staffs developed more complete scope definition, their procurement staffs prepared the commercial portions of requisition packages, issued these packages to approved vendors for quotation and analyzed the proposals recived. When the project receives full funding and a release to purchase, purchase orders will be awarded first for critical equipment, then for other equipment, and finally for all other material. Critical pieces of equipment are those pieces of equipment where a delay in the design, fabrication or delivery periods will affect the overall project ompletion date. Critical equipment identified thus far is the gasifiers, $\infty$ al locks, ash locks, boilers, compressors, oxygen plant equipment and superheaters.

IIIA. Procurement Activities - Chronological

November - December, 1979

Requests for quotation (RFQ's) for Lurgi gasifiers, cal locks and ash locks were prepared and issued.

January - March, 1980

1. Responses to RFQ's for Lurgi gasifiers, coal locks and ash lorks were recived, and analyses begun.

2. CEIKE prepared and issued RFQ's for compressore, the oxygen plant, the boiler plant, the construction housinq facility, pre-engineered buildings and site preparation. 
April - June, 1980

1. RFQ's for Lurgi waste heat exchangers, phenosolvan and naphtha extractors and pumps, gasifier coal grates, hydraulic and lubrication systems, and coal scrapers and feed chutes were prepared and issued to approved vendors.

2. Responses to RFQ's for Lurgi methanation reactors and direct contact oolers were recived and analyzed by Lurgi.

3. RFQ's for cooling water pumps and drivers and for the cooling tower were issued to approved vendors.

4. CELKE received and began evaluation of quotes for the compressors, boiler plant and site preparation.

5. CELKE prepared and issued RFQ's for jrocess heat exchangers, colums, reactors, vessels, water treatment equipment, major tanks, electrical equipment (switchgear, transformers, and motoc control centers).

6. CEIKE received vendor quotes and completed evaluation of the bids for the construction housing facilities, the site preparation and the pre-engineered buildings. Purchase orders were awarded for site preparation and the three buildings (warehouse, field office, gatehouse and medical facility).

July - September, 1980

1. Lurgi continued preparation of RFQ's for the remaining pieces of proprietary equipment. They also received and evaluated vendor responses to RFQ's for naiphtha and phenosolvan extractor pumps, waste heat exchangers, and scrapers.

2. CELKE prepared and issuad RFQ's for small and medium size motors, substation transformers and structural steel.

3. CELKE received and began evaluation of the quotes for the oxygen plant and the cooling water pumps.

4. CETKE issued RFQ's for administration area building foundations and for process area piling. When quotes for these RFQ's were received, evaluation was made and purchase orders awarded. 
5. Due to the project delay CELKE began negotiating bid extensions from vendors. This was necessary to prevent below-budget quotes from expiring.

October - November, 1980

1. CELKE completed evaluation of bids for compressors, cooling water pumps, the oxygen plant, the boiler plant and the cooling tower.

2. Lurgi awarded two conditional purchase orders for gasifiers. Each order was for seven gasifiers and both vendors were released to begin design engineering.

3. The onditional purchase order was defined as an ayseritiil between a buyer and scllcx in whioh tho seller is awaripen an order to provide materials such that the buyer will have zero cost liability until notification or release is given to the seller to first commence engineering and later to commence procurement and fabrication of material. This release will be given when all full financing and other necessary approvals are recived for the project. 
A summary of major procurement events during the past year is as follows:

\begin{tabular}{|c|c|c|c|c|}
\hline $\begin{array}{l}\text { Type of } \\
\text { Equipment }\end{array}$ & Issue $\mathrm{RFQ}$ & $\begin{array}{l}\text { Bid } \\
\text { Recived }\end{array}$ & $\begin{array}{l}\text { Bid Evaluation } \\
\text { Complete }\end{array}$ & P.O. Date \\
\hline Gasifiers & $12-15-79$ & $2-15-30$ & $4-16-80$ & $\begin{array}{l}10-15-80 \\
\text { Engr. Only }\end{array}$ \\
\hline compressors & $3-15-80$ & $6-05-80$ & $10-21-80$ & - \\
\hline $\begin{array}{l}\text { Cooling Water } \\
\text { Pumps }\end{array}$ & $5-07-80$ & $7-21-80$ & $11-14-80$ & - \\
\hline Oxygen Plant & $3-10-80$ & $7-23-80$ & $10-23-80$ & - \\
\hline Boiler Plant & $2-01-80$ & $6-23-80$ & $10-03-80$ & - \\
\hline $\begin{array}{l}\text { Construction } \\
\text { Housing } \\
\text { Facilities }\end{array}$ & $2-14-80$ & $4-11-80$ & $6-11-80$ & - \\
\hline Site Preparation & $2-07-80$ & $3-26-80$ & $5-13-80$ & $6-20-80$ \\
\hline Cooling Tower & $4-15-80$ & $5-30-80$ & $11-15-80$ & - \\
\hline $\begin{array}{l}\text { Pre-Engineered } \\
\text { Buildings }\end{array}$ & $2-07-80$ & $3-19-80$ & $4-21-80$ & $6-23-80$ \\
\hline $\begin{array}{l}\text { Building } \\
\text { Foundations }\end{array}$ & $8-19-80$ & $9-03-80$ & $9-05-80$ & $9-10-80$ \\
\hline Piling & $8-11-80$ & $9-05-80$ & $9-09-80$ & $10-06-80$ \\
\hline
\end{tabular}


CELKE and Lurgi spent approximately 29,400 procurement manhours during this period and issued 1,301 of the required 2,574 requests for quotation for major equipment. These RFQ's represent about $80 \%$ of the dollar value of the major equipment estimate. As the responses from the vendors were recived, CFLKE and Lurgi evaluated the bids and prepared RFQ's. Upon review and approval of these recommendations by ANG and after pre-award meetings with the successful vendors, CELIE and Lurgi will award conditional purchase orders.

CETKE also issued sixteen of the required forty-seven request's for quotation for subcontract packages. Of these sixteen RFQ's, six have been awarded as part of the 1980 construction program. The evaluations of three of the remaining packages have been completed and the renalnder are in progness. 
This activity consisted of Planning, Scheduling and cost Control functions ralated to two major areas of Project control:

- Project control for work included within this Cooperative Agreement, and

- Project control for the entire fill project beyond this cooperative Agreement.

Engineering Schedules were developed which specifically applied to the work to be accomplished under this coperative agreement as well as those schedules reaching out into the 1981 work plan. In addition, Engineering-Procurement-construction (E-P-C) Schedules were developed, which provided the guidelines for all detailed scheduling required on the entire project.

The Program Scheduling Status Report (PSSR), the scheduling and monitoring system for project procurement was finalized and implemented for the project.

Monthly Progress Reports covering the period and to-date status of all project activities were implemented, and monthly Cost Reports covering the period and to-date status of all project expenditures were implemented as part of the work accom plished under this Cooperative Agreement.

A formal procedure was finalized and implemented covering the management of escalation for all project costs. This control procedure provides for the calculation of actual escalation as it occurs for each commodity item and labor included in the project cost control system, which is then incorporated into the project. costs on a quarterly basis by Project Mamagement. This is a major cost control tool.

The original Project control Estimate, developed in June, 1978, was revised twice during the life of this cooperative agreement. First revision was finalized and approved in February, 1980 and the second occirred september 15, 1980 and represents the latest project oost study to-date for this project.

In general, systems required for control of the entire project were finalized and implemented, placing the project in a state of readiness for management control of cost and schedule when full project release is provided.

Monthly reports were prepared and submitted during the life of this Cooperative Agreement and they provide a history of each month's performance. 